\title{
Vitamin D status among adolescents in Europe: the Healthy Lifestyle in Europe by Nutrition in Adolescence study
}

\author{
Marcela González-Gross ${ }^{1,2_{*}} \dagger$, Jara Valtueña ${ }^{1,3} \dagger$, Christina Breidenassel $^{2}$, Luis A. Moreno ${ }^{4,5}$, \\ Marika Ferrari ${ }^{3}$, Matilde Kersting ${ }^{6}$, Stefaan De Henauw ${ }^{7}$, Frederic Gottrand ${ }^{8}$, Elena Azzini ${ }^{3}$, \\ Kurt Widhalm ${ }^{9}$, Anthony Kafatos ${ }^{10}$, Yannis Manios ${ }^{11}$ and Peter Stehle ${ }^{2}$ on behalf of the \\ HELENA Study Group \\ ${ }^{1}$ Department of Health and Human Performance, Faculty of Physical Activity and Sport Sciences (INEF), Universidad \\ Politécnica de Madrid, C/Martín Fierro, 7, 28040 Madrid, Spain \\ ${ }^{2}$ Institut für Ernährungs- und Lebensmittelwissenschaften - Humanernährung, Rheinische Friedrich-Wilhelms Universität, \\ Bonn, Germany \\ ${ }^{3}$ National Research Institute on Food and Nutrition, Rome, Italy \\ ${ }^{4}$ Growth, Exercise, Nutrition and Development (GENUD) Research Group, Universidad de Zaragoza, Zaragoza, Spain \\ ${ }^{5}$ Escuela Universitaria de Ciencias de la Salud, Universidad de Zaragoza, Zaragoza, Spain \\ ${ }^{6}$ Research Institute of Child Nutrition Dortmund, Rheinische Friedrich-Wilhelms Universität, Bonn, Germany \\ ${ }^{7}$ Department of Public Health, Ghent University, Ghent, Belgium \\ ${ }^{8}$ Inserm U995, IFR114, University Lille 2, Lille, France \\ ${ }^{9}$ Department of Paediatrics, Medical University of Vienna, Vienna, Austria \\ ${ }^{10}$ Preventive Medicine and Nutrition Clinic, University of Crete School of Medicine, Iraclion, Crete, Greece \\ ${ }^{11}$ Department of Nutrition and Dietetics, Harokopio University, Athens, Greece
}

(Received 12 November 2010 - Revised 23 May 2011 - Accepted 31 May 2011 - First published online 17 August 2011)

\section{Abstract}

An adequate vitamin D status is essential during childhood and adolescence, for its important role in cell growth, skeletal structure and development. It also reduces the risk of conditions such as CVD, osteoporosis, diabetes mellitus, infections and autoimmune disease. As comparable data on the European level are lacking, assessment of vitamin D concentrations was included in the Healthy Lifestyle in Europe by Nutrition in Adolescence (HELENA) study. Fasting blood samples were obtained from a subsample of 1006 adolescents ( 470 males; $46.8 \%$ ) with an age range of $12.5-17.5$ years, selected in the ten HELENA cities in the nine European countries participating in this cross-sectional study, and analysed for 25-hydroxycholecalciferol (25(OH)D) by ELISA using EDTA plasma. As specific reference values for adolescents are missing, percentile distribution were computed by age and sex. Median 25(OH)D levels for the whole population were $57 \cdot 1 \mathrm{nmol} / 1$ ( 5 th percentile $24.3 \mathrm{nmol} / 1$, 95 th percentile $99 \cdot 05 \mathrm{nmol} / 1)$. Vitamin D status was classified into four groups according to international guidelines (sufficiency/optimal levels $\geq 75 \mathrm{nmol} / 1$; insufficiency $50-75 \mathrm{nmol} / 1$; deficiency $27.5-49 \cdot 99 \mathrm{nmol} / 1$ and severe deficiency $<27.5 \mathrm{nmol} / \mathrm{l}$ ). About $80 \%$ of the sample had suboptimal levels (39\% had insufficient, $27 \%$ deficient and $15 \%$ severely deficient levels). Vitamin D concentrations increased with age $(P<0 \cdot 01)$ and tended to decrease according to BMI. Geographical differences were also identified. Our study results indicate that vitamin D deficiency is a highly prevalent condition in European adolescents and should be a matter of concern for public health authorities.

Key words: Adolescents: Vitamin D: Prevention: Europe

Adolescents are considered as a risk group for malnutrition because of their increasing needs of nutrients and energy for adequate growth and development that vary with age $^{(1-3)}$. Specifically different levels of vitamin D deficiency at these early ages could be considered a risk factor for osteomalacia $^{(4-6)}$, impaired cognitive function and concentration problems ${ }^{(7)}$, hyperactivity ${ }^{(8)}$ and immune system deficiency $^{(4)}$. Inadequate vitamin $\mathrm{D}$ levels have also been related to other diseases such as diabetes, multiple sclerosis and cancer $^{(9-11)}$. One of the most important applications

Abbreviations: 25(OH)D, 25-hydroxycholecalciferol; HELENA, Healthy Lifestyle in Europe by Nutrition in Adolescence.

*Corresponding author: Professor M. González-Gross, email marcela.gonzalez.gross@upm.es

†Equal authorship. 
of vitamin D assessment in adolescence is related to bone health ${ }^{(12)}$ and reaching an optimal peak bone mass in adulthood $^{(13,14)}$. The main sources of vitamin D are food intake and subcutaneous skin synthesis, under UV light (290-315 nm) exposure. However, due to the geographical situation of our continent, vitamin D synthesis may not compensate for a low nutritional intake ${ }^{(15)}$. Subclinical vitamin D deficiency could remain undetected as it is not routinely screened for in these population groups. The main circulating vitamin D metabolite, 25-hydroxycholecalciferol (25(OH)D), has been proposed as the best indicator of vitamin D status, because it represents not only the amount consumed through diet and supplements but also the subcutaneous synthesis $^{(15-18)}$.

Scientific knowledge about vitamin D status in the period of adolescence in both developed and developing countries is still scarce. Several studies on the status of vitamin D in European adolescents have been carried out in the last decade, but only a few have used a significant number of subjects. As we have recently reviewed ${ }^{(19)}$, comparison of the data is not always possible due to the use of different age ranges, different methods, different ways of presenting them in the different studies and a lack of consensus on cut-off levels. Proposed deficient and sufficient 25(OH)D vitamin concentrations vary from 20 to $100 \mathrm{nmol} / 1$ depending on the studies ${ }^{(20-22)}$. While there are no universally accepted blood 25(OH)D thresholds to define adequacy in adolescents, the following set has been proposed: concentrations of 25(OH)D less than $75 \mathrm{nmol} / \mathrm{l}$ as insufficient, concentrations less than $50 \mathrm{nmol} / \mathrm{l}$ as deficient and severe vitamin D deficiency when values are less than $27.5 \mathrm{nmol} / \mathrm{l}^{(23)}$. The proposed reference value for insufficiency in children $(<75 \mathrm{nmol} / \mathrm{l})$ has been extrapolated from adult data ${ }^{(18)}$.

One of the main aims of the Healthy Lifestyle in Europe by Nutrition in Adolescence (HELENA) study was to provide, for the first time, comparable data about micronutrient status in European adolescents ${ }^{(24)}$. The main objective of the present study was to describe vitamin D status in adolescents and to analyse vitamin plasma concentrations by sex, age and weight status, thus contributing to establishing reference values that are not available for the adolescent population $^{(25,26)}$.

\section{Subjects and methods}

\section{Subjects, recruitment and study design}

The HELENA cross-sectional study was a multi-centre crosssectional study aiming to obtain reliable and comparable data from a random sample of 3000 European adolescents aged between 12.5 and 17.49 years on a broad battery of nutrition and health-related parameters ${ }^{(24,27)}$. Subjects were recruited by a school-based, multi-step, stratified random and cluster sampling selection. Criteria for city selection included geographic balance and the presence of an experienced research group. The sample size was calculated to establish distributions of relevant study variables. Exclusion criteria were limited to subjects who were not able to speak the local language, who were participating simultaneously in another clinical trial, who were aged $<12.5$ or $>17.5$ years and who had suffered from acute infection 1 week before the visit. Exclusion from the study was decided a posteriori, without the knowledge of the affected subjects, to avoid non-desirable situations, and so whole classes were included. A complete description of the design and implementation of the study has been published elsewhere ${ }^{(24)}$.

In the same manner as described earlier, a subsample of 1006 adolescents was selected for blood sampling in the ten HELENA cities in nine European countries: Athens (Greece), Dortmund (Germany), Ghent (Belgium), Heraklion (Greece), Lille (France), Pecs (Hungary), Rome (Italy), Stockholm (Sweden), Vienna (Austria) and Zaragoza (Spain). The protocol was approved by the corresponding human research review committees of Bonn (Dortmund), Lille, Rome, Zaragoza, Athens, Heraklion, Pecs, Ghent, Stockholm and Vienna. The study was performed following the ethical guidelines of the Declaration of Helsinki 1964 (revision of Edinburgh 2000), Convention of Oviedo (1997), the Good Clinical Practice, and the legislation about clinical research in human subjects in each of the participating countries. Informed written consent was obtained from subjects and parents or guardians. A complete description of ethical issues and good clinical practice within the HELENA crosssectional study has been published elsewhere ${ }^{(28)}$.

\section{Specimen collection and biochemical analyses}

A specific handling, transport and traceability system for biological samples was developed for the HELENA study and has already been described by González-Gross et al. ${ }^{(29)}$. Blood samples were obtained between October 2006 and June 2007, and in October 2007 (see Annex). A bloodsampling calendar was developed to coordinate the fieldwork between the centres and the central laboratory at the University of Bonn (Institut für Ernährungs- und Lebensmittelwissenschaften (IEL); Bonn, Germany). The blood sampling date depended on local fieldwork planning, the agreement of the school, and availability and capacity of the lab at IEL. Fasting blood samples were collected by venepuncture at school between 08.00 and 10.00 hours. For the measurement of vitamin D, blood was collected in EDTA tubes and transported at room temperature to the central laboratory at IEL within $24 \mathrm{~h}$. There it was centrifuged at $3500 \mathrm{rpm}$ for $15 \mathrm{~min}$ at $4^{\circ} \mathrm{C}$ and the supernatant was stored at $-80^{\circ} \mathrm{C}$ until assayed. The samples were kept stable for $24 \mathrm{~h}$ at room temperature (CV: $4.3 \%)$.

Serum concentration of $25(\mathrm{OH}) \mathrm{D}$ is considered to be the most reliable measure of overall vitamin D status and thus can be used to determine whether a subject is vitamin D sufficient. Plasma 25(OH)D was analysed by ELISA using a kit (OCTEIA 25(OH)D) from Immunodiagnostic System (Frankfurt am Main, Germany) and measured with a Sunrise ${ }^{\mathrm{TM}}$ Photometer by TECAN (Männedorf, Germany). The IDS OCTEIA 25(OH)D kit is an enzyme immunoassay intended for the quantitative determination of $25(\mathrm{OH}) \mathrm{D}$ and other hydroxylated metabolites in human serum or plasma. Results are used in conjunction 
with other clinical and laboratory data to assist the clinician in the assessment of vitamin D sufficiency. The sensitivity of this method is $5 \mathrm{nmol} / 125(\mathrm{OH}) \mathrm{D}$ and the variation is less than $6 \%$. The mean recovery of $25(\mathrm{OH}) \mathrm{D}$ is $101 \%$. The $\mathrm{CV}$ for the method was less than $1 \%$.

\section{Physical examination}

The adolescents had their height and weight measured by trained researchers in a standardised way: weight was recorded to the nearest $0.1 \mathrm{~kg}$, using an electronic scale (type SECA 861; SECA, Hamburg, Germany) and height was recorded to the nearest $0 \cdot 1 \mathrm{~cm}$, using a telescopic height measuring instrument (type SECA 225). The BMI was calculated from their measured height and weight $(\mathrm{BMI}=$ weight divided by height squared, $\left.\left(\mathrm{kg} / \mathrm{m}^{2}\right)\right)$. International age- and sex-specific cut-off points ${ }^{(30,31)}$ were used to assess BMI category (underweight/ normal weight/overweight/obese). The complete description of the anthropometric measurements of the study has been published elsewhere ${ }^{(32)}$. A physician classified the adolescents into one of the five maturation stages described by Tanner \& Whitehouse $^{(33)}$.

\section{Statistical analysis}

$25(\mathrm{OH}) \mathrm{D}$ showed a normal histogram distribution. Descriptive statistics were performed and values are shown as mean, standard deviation, percentile, median, minimum and maximum. For this study, vitamin D status was classified into four groups (vitamin D sufficiency/optimal levels $\geq 75 \mathrm{nmol} / \mathrm{l}$; insufficiency $50-75 \mathrm{nmol} / 1$; deficiency $27.5-49.99 \mathrm{nmol} / 1$ and severe deficiency $<27.5 \mathrm{nmol} / \mathrm{l})$ following international guidelines ${ }^{(18,34,35)}$. The differences between sex, age groups and BMI groups were analysed using one-way ANOVA. All the analyses were adjusted by a weighting factor to balance the sample according to the age and sex distribution of the theoretical sample, to guarantee representation of each of the stratified groups.

To provide percentile value curves for European adolescents, we analysed vitamin D data by maximum penalised likelihood using the least mean square statistical method for boys and girls separately ${ }^{(36,37)}$. We derived smoothed centile charts using the least mean square method. This estimates the measurement centiles in terms of three age-sex-specific cubic spline curves: the L curve (Box-Cox power to remove skewness), M curve (median) and S curve (CV). For the construction of the percentile curves, data were imported into the LmsChartMaker software (version 2.3; by Tim Cole and Huiqi Pan, Harlow Healthcare, South Shields, Tyne and Wear, UK) and the L, M and $S$ curves were estimated. The rest of the data were analysed using SPSS version 18.0 (SPSS Inc., Chicago, IL, USA).

\section{Results}

Descriptive characteristics and mean vitamin D concentrations of the study sample by age and sex are shown in Tables 1 and 2. Girls had slightly higher mean concentrations than boys. Prevalence rates of vitamin D status according to the aforementioned sufficient-deficient classification are shown in Fig. 1. Considering the cut-off set for adults at $75 \mathrm{nmol} / \mathrm{l}$, approximately $80 \%$ of the sample was below the optimal levels. A slightly higher percentage of females (22.2\%) had sufficient $25(\mathrm{OH}) \mathrm{D}$ concentrations compared to males (15.1\%). Regarding 25(OH)D deficiency $(<27.5 \mathrm{nmol} / \mathrm{l})$, an equal and high proportion of males and females revealed this status $(15 \%)$.

There is a tendency of increasing $25(\mathrm{OH}) \mathrm{D}$ concentrations with increasing age for the whole group $(P<0 \cdot 001)$, which is only significant in girls when the sample is split by sex $(P<0.05)$. Percentile distribution by age and sex for the whole sample is shown in Table 2. 25(OH)D sufficiency $(>75 \mathrm{nmol} / \mathrm{l})$ is reached at lower percentiles with increasing age. That means that at increasing ages there are fewer subjects with insufficient $25(\mathrm{OH}) \mathrm{D}$ levels. Regarding deficiency, the fifth percentile of $25(\mathrm{OH}) \mathrm{D}$ in both males and females is close to the level of $<27.5 \mathrm{nmol} / 1$ for all ages.

Fig. 2 shows smoothed centile curves (P5, P25, P50, P75, P95) for $25(\mathrm{OH}) \mathrm{D}$ levels studied by age and sex. Concentrations were similar in boys and girls, although in boys, first a decrease and after the age of 14 years an increase is observed. In girls, the curves seem to indicate that the decrease comes before the age of 13 years, because at age 13 years a slightly progressive increase with age with a similar slope to that of the boys was observed. In both boys and girls, the trend to higher 25(OH)D levels is seen for those at P75 and P95, whereas at the other lower levels there is a trend to stability.

Table 1. Descriptive characteristics of participants (Mean values, standard deviations and number of participants)

\begin{tabular}{|c|c|c|c|c|c|c|}
\hline & \multicolumn{2}{|c|}{ All $(n$ 1006) } & \multicolumn{2}{|c|}{ Male $(n 470)$} & \multicolumn{2}{|c|}{ Female ( $n 536)$} \\
\hline & Mean & SD & Mean & SD & Mean & SD \\
\hline Age (years) & 14.9 & $1 \cdot 2$ & 14.9 & $1 \cdot 2$ & 14.9 & $1 \cdot 2$ \\
\hline $\begin{array}{l}\text { Sexual maturation: } \\
\text { Tanner stages I/II/III/IV/V (\%) }\end{array}$ & \multicolumn{2}{|c|}{$0 / 5 / 19 / 44 / 37$} & \multicolumn{2}{|c|}{$2 / 6 / 19 / 42 / 31$} & \multicolumn{2}{|c|}{$0 / 4 / 19 / 45 / 32$} \\
\hline Height $(\mathrm{cm})$ & 165.8 & $9 \cdot 3$ & $170 \cdot 2$ & 9.7 & 161.9 & $7 \cdot 0$ \\
\hline Weight (kg) & $59 \cdot 0$ & $12 \cdot 3$ & $62 \cdot 1$ & 13.7 & $56 \cdot 2$ & $10 \cdot 2$ \\
\hline $\mathrm{BMI}\left(\mathrm{kg} / \mathrm{m}^{2}\right)$ & 21.4 & 3.6 & $21 \cdot 3$ & 3.8 & 21.4 & 3.4 \\
\hline $25(\mathrm{OH}) \mathrm{D}(\mathrm{nmol} / \mathrm{l})$ & 58.8 & 23.1 & 57.4 & $22 \cdot 7$ & 60.0 & 23.4 \\
\hline
\end{tabular}

25(OH)D, 25-hydroxycholecalciferol. 
Table 2. 25-Hydroxycholecalciferol concentrations by age and sex in European adolescents (nmol/l)

(Mean values, standard deviations, number of participants and percentiles)

\begin{tabular}{|c|c|c|c|c|c|c|c|c|c|c|c|c|}
\hline & $n$ & Mean & SD & P2.5 & P5 & P10 & P25 & P50 & P75 & P90 & P95 & P97.5 \\
\hline Total (n 1006) & 1006 & $58 \cdot 8$ & $23 \cdot 1$ & $20 \cdot 9$ & 24.9 & 31.6 & 43.5 & $57 \cdot 0$ & $71 \cdot 3$ & $87 \cdot 8$ & $99 \cdot 1$ & $112 \cdot 9$ \\
\hline Males $(n$ 470) $\dagger$ & 470 & $57 \cdot 4$ & $22 \cdot 7$ & $21 \cdot 6$ & $24 \cdot 3$ & 32 & $42 \cdot 6$ & 56.0 & $69 \cdot 1$ & $86 \cdot 7$ & $96 \cdot 4$ & $107 \cdot 4$ \\
\hline Age 13 (years) & 124 & $56 \cdot 9$ & $22 \cdot 8$ & $24 \cdot 2$ & $27 \cdot 0$ & 32.5 & 41.8 & 55.8 & $66 \cdot 6$ & $78 \cdot 3$ & 101.5 & $132 \cdot 0$ \\
\hline Age 14 (years) & 124 & $55 \cdot 6$ & $20 \cdot 6$ & $22 \cdot 5$ & 24.9 & $31 \cdot 7$ & $42 \cdot 3$ & 53.5 & $65 \cdot 9$ & 81.9 & $91 \cdot 2$ & $96 \cdot 4$ \\
\hline Age 15 (years) & 122 & $58 \cdot 3$ & $21 \cdot 3$ & $20 \cdot 7$ & $24 \cdot 4$ & 33.6 & 44.8 & $56 \cdot 2$ & 71.3 & 89.0 & 94.9 & $102 \cdot 0$ \\
\hline Age 16 (years) & 99 & $59 \cdot 3$ & $26 \cdot 5$ & $20 \cdot 4$ & $22 \cdot 6$ & 24.9 & 43.0 & $59 \cdot 6$ & $70 \cdot 8$ & $92 \cdot 3$ & $107 \cdot 6$ & 121.9 \\
\hline Females $(n 536) \dagger$ & 536 & $60 \cdot 0$ & 23.4 & $20 \cdot 9$ & 25.5 & $31 \cdot 0$ & 44.8 & 57.9 & $74 \cdot 3$ & 88.7 & 103.0 & $115 \cdot 9$ \\
\hline Age 13 (years) & 133 & $52 \cdot 1^{*}$ & $19 \cdot 2$ & $17 \cdot 0$ & $20 \cdot 9$ & $25 \cdot 6$ & $40 \cdot 6$ & $50 \cdot 8$ & $64 \cdot 0$ & $78 \cdot 0$ & $85 \cdot 8$ & $96 \cdot 8$ \\
\hline Age 14 (years) & 140 & $62 \cdot 5^{*}$ & $22 \cdot 3$ & $20 \cdot 9$ & $27 \cdot 8$ & 33.6 & 49.1 & $62 \cdot 0$ & $77 \cdot 9$ & $90 \cdot 2$ & $99 \cdot 2$ & $111 \cdot 3$ \\
\hline Age 15 (years) & 143 & $59.6^{*}$ & $20 \cdot 8$ & 21.3 & $26 \cdot 0$ & $36 \cdot 2$ & $46 \cdot 6$ & $56 \cdot 8$ & 71.5 & $90 \cdot 2$ & $97 \cdot 2$ & $106 \cdot 0$ \\
\hline Age 16 (years) & 120 & $66 \cdot 2^{*}$ & $28 \cdot 9$ & $25 \cdot 6$ & $26 \cdot 9$ & $27 \cdot 4$ & $46 \cdot 4$ & 61.8 & $80 \cdot 3$ & $109 \cdot 3$ & $120 \cdot 8$ & 133.5 \\
\hline
\end{tabular}

* Mean values were significantly different between the 13 years age group and the rest of the age groups $(P<0.05)$.

†Four age groups: 13 years, age between 12.5 and 13.99 years; 14 years, age between 14 and 14.99 years; 15 years, age between 15 and 15.99 years; 16 years, age between 16 and 17.49 years.

When analysing the data according to BMI, a non-significant and progressive decrease of $25(\mathrm{OH}) \mathrm{D}$ concentrations with increasing BMI is observed, the lowest levels being observed in obese adolescents (equivalent to BMI $>30 \mathrm{~kg} / \mathrm{m}^{2}$; Table 3). The highest mean levels were for boys in the underweight group and for girls in the optimal weight group (66.6 (sD 28.9) and 61.1 (sD 23.5) nmol/1, respectively). Most of the adolescents had optimal weight status (BMI $20-25 \mathrm{~kg} / \mathrm{m}^{2}$ ).

Table 4 shows $25(\mathrm{OH}) \mathrm{D}$ levels by study centre, for the whole group split by sex. The highest levels were obtained in Rome, Athens, Vienna and Zaragoza, and the lowest levels were found in Dortmund, Heraklion and Ghent for the whole group, where the sampling procedure went on for most of the academic year. In none of the cities were mean levels above the proposed cut-off of $75 \mathrm{nmol} / \mathrm{l}$. Girls had higher mean levels in all cities except for Athens, Pecs and Lille. Deficient levels $(<50 \mathrm{nmol} / \mathrm{l})$ were highest in
Dortmund (62.9\% of the population) and Ghent $(53.3 \%)$, and lowest in Athens (25.7\%) and Rome (26.4\%) (data not shown).

\section{Discussion}

Since the publication of the results of the SENECA (Survey in Europe on Nutrition and the Elderly; a Concerted Action) study $^{(38)}$, where unexpectedly only $3.5 \%$ of the analysed European elderly presented optimum 25(OH)D levels ( $>60 \mathrm{nmol} / \mathrm{l}$ ), public health authorities have been concerned about the widespread 25(OH)D deficiency in the European population. To the best of our knowledge, the data obtained in the framework of the HELENA study are the first to aim at establishing descriptive 25(OH)D status in adolescents at a European level. According to the Institute of Medicine report 2011, vitamin D intake for bone health should correspond to

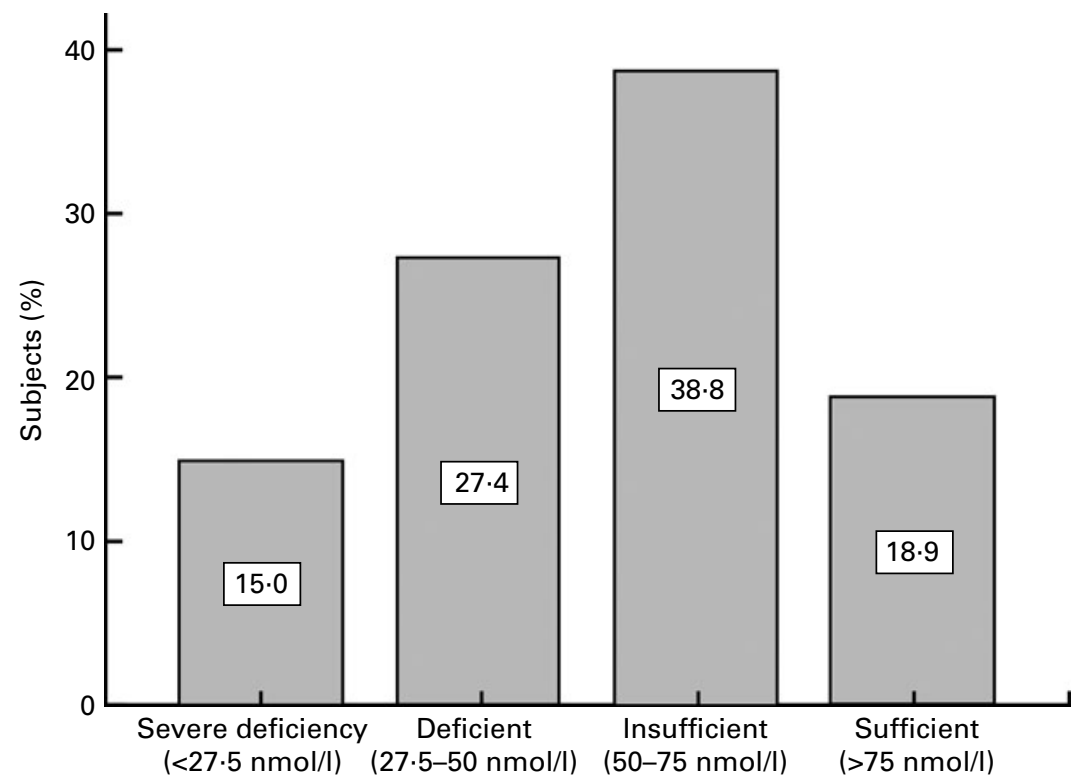

$25(\mathrm{OH}) \mathrm{D}$ status groups

Fig. 1. 25-Hydroxycholecalciferol $(25(\mathrm{OH}) \mathrm{D})$ status classification. 

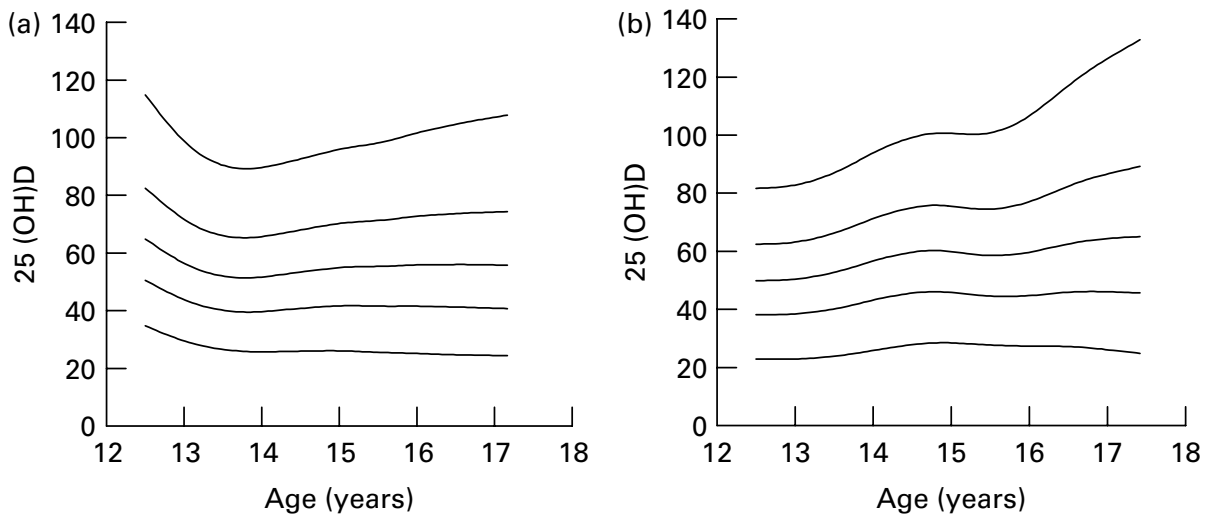

Fig. 2. Smoothed (least mean square method) centile curves (from the bottom to the top: P5, P25, P50, P75, P95) of 25-hydroxycholecalciferol (25(OH)D) plasma concentrations (nmol/l) in (a) males and (b) females.

a serum 25(OH)D level of at least $20 \mathrm{ng} / \mathrm{ml}(50 \mathrm{nmol} /)^{(23)}$. Our study results showed that approximately $40 \%$ of the subjects had deficient levels lower than $50 \mathrm{nmol} / 1$, $15 \%$ with levels less than $27.5 \mathrm{nmol} / 1$. None of the subjects had levels less than $10 \mathrm{nmol} / \mathrm{l}$, which, according to the literature, elevates the risk for osteomalacia and rickets ${ }^{(14,39-42)}$. The HELENA percentile distribution is in agreement with data coming from other studies ${ }^{(20,24,27,28,43,44)}$. When analysing the percentile distribution of $25(\mathrm{OH}) \mathrm{D}$ we observed that the fifth percentile of $25(\mathrm{OH}) \mathrm{D}$ in both males and females, stratified by age, is close to the level of $<27.5 \mathrm{nmol} / 1$ for all ages. A general hypovitaminosis problem in adolescence varying from 13 to $72 \%$ has already been postulated in studies performed in several European countries ${ }^{(20,24,27,28,43,44)}$, the USA and Canada ${ }^{(45-49)}$. In a recent study published by Dong et $a l .{ }^{(47)}$, the overall prevalence of vitamin D insufficiency and deficiency in US children and adolescents was 56.4 and $28.8 \%$, respectively. All together, the high levels of vitamin D deficiency found in the present and other studies should be treated with caution. Regarding our percentile distribution, the median value of a $25(\mathrm{OH}) \mathrm{D}$ concentration in our European adolescents is close to $60 \mathrm{nmol} / \mathrm{l}$, much lower than the optimal levels proposed of $75 \mathrm{nmol} / 1$. Following LanhamNew et $a l .{ }^{(50)}$, any discussion of an 'optimal' serum $25(\mathrm{OH}) \mathrm{D}$ concentration needs to define 'optimal' with care since it is important to consider the normal distribution of requirements and the vitamin D needs for a wide range of outcomes. In addition, in the Rank Forum on Vitamin D, 2009, there was also some uncertainty about the strength of evidence for the need to aim for substantially higher concentrations (25(OH)D) concentrations $>75 \mathrm{nmol} / \mathrm{l}^{(50)}$.

Analysing vitamin $\mathrm{D}$ status by age, we have observed a steady increase in $25(\mathrm{OH}) \mathrm{D}$ concentrations with increasing age but which is only significant in girls. This is not in line with other published data. Koenig \& Elmadfa ${ }^{(51)}$ found a decrease in $25(\mathrm{OH}) \mathrm{D}$ serum concentrations in Austrian adolescents up to 14 years of age and a slow increase between the ages of 15 and 19 years. Similar findings were observed by Gregory et al. ${ }^{(22)}$, with a significant reduction in $25(\mathrm{OH}) \mathrm{D}$ serum concentrations according to increasing age in adolescence. Dong et al. ${ }^{(47)}$ concluded in their study that plasma $25(\mathrm{OH}) \mathrm{D}$ levels were not associated with age $(P=0 \cdot 460)$. Conversely, Bonofiglio et al. ${ }^{(25)}$ found higher $25(\mathrm{OH}) \mathrm{D}$ serum concentrations in post-menarcheal girls when compared with pre-menarcheal girls. These higher concentrations were explained as an increase in the binding protein of vitamin $\mathrm{D}$ because of higher oestrogen levels caused by menarche. This could also be the explanation for the differences

Table 3. 25 -Hydroxycholecalciferol concentrations by BMI $\left(\mathrm{kg} / \mathrm{m}^{2}\right)$ in European adolescents (nmol/l) (Mean values, standard deviations, number of participants, minimum and maximum values)

\begin{tabular}{|c|c|c|c|c|c|c|}
\hline & BMI $\left(\mathrm{kg} / \mathrm{m}^{2}\right)^{*}$ & $n$ & Mean† & SD & Minimum & Maximum \\
\hline \multirow[t]{4}{*}{ All $(n$ 1006) } & Low & 58 & $61 \cdot 1$ & 26.9 & $13 \cdot 7$ & $140 \cdot 0$ \\
\hline & Optimal & 728 & $59 \cdot 3$ & 23.7 & $12 \cdot 1$ & 174.0 \\
\hline & Overweight & 167 & $56 \cdot 9$ & $20 \cdot 3$ & 11.4 & $120 \cdot 8$ \\
\hline & Obese & 52 & $55 \cdot 3$ & 18.4 & 23.8 & 111.3 \\
\hline \multirow[t]{4}{*}{ Males ( $n$ 470) } & Low & 26 & $66 \cdot 6$ & 28.9 & $20 \cdot 7$ & 138.1 \\
\hline & Optimal & 331 & $57 \cdot 1$ & 23.7 & $12 \cdot 2$ & 174.0 \\
\hline & Overweight & 82 & $57 \cdot 0$ & $17 \cdot 1$ & $21 \cdot 3$ & 97.9 \\
\hline & Obese & 31 & 54.8 & $16 \cdot 4$ & $26 \cdot 4$ & 101.5 \\
\hline \multirow[t]{4}{*}{ Females ( $n 536)$} & Low & 32 & $56 \cdot 8$ & 24.9 & $13 \cdot 8$ & $140 \cdot 0$ \\
\hline & Optimal & 397 & $61 \cdot 1$ & 23.5 & $12 \cdot 1$ & $160 \cdot 8$ \\
\hline & Overweight & 86 & $56 \cdot 8$ & 23.0 & 11.4 & $120 \cdot 8$ \\
\hline & Obese & 21 & $56 \cdot 1$ & 21.4 & $23 \cdot 8$ & 111.3 \\
\hline
\end{tabular}

*BMI category calculated using polynomial from Cole et al. ${ }^{(36,37)}$. Four BMI groups: low ( $<18.5$ in adults), optimal (18.5-25 in adults), overweight (25-30 in adults), obese ( $>30$ in adults). † Mean values were not significantly different. 
Table 4. Mean 25-hydroxycholecalciferol $(25(\mathrm{OH}) \mathrm{D})$ concentrations $(\mathrm{nmol} / \mathrm{l})$ in the Healthy Lifestyle in Europe by Nutrition in Adolescence cities (Mean values, standard deviations, minimum and maximum values)

\begin{tabular}{|c|c|c|c|c|c|c|c|c|c|c|}
\hline & \multicolumn{10}{|c|}{$25(\mathrm{OH}) \mathrm{D}(\mathrm{nmol} / \mathrm{l})$} \\
\hline & \multicolumn{2}{|c|}{ All } & \multicolumn{4}{|c|}{ Male } & \multicolumn{4}{|c|}{ Female } \\
\hline & Mean & SD & Mean & SD & Minimum & Maximum & Mean & SD & Minimum & Maximum \\
\hline Rome in Italy & $70 \cdot 0$ & $19 \cdot 3$ & $67 \cdot 7$ & 17.5 & $37 \cdot 2$ & $116 \cdot 3$ & $71 \cdot 8$ & 20.5 & $25 \cdot 6$ & $111 \cdot 3$ \\
\hline Athens in Greece & $68 \cdot 2$ & $20 \cdot 8$ & $70 \cdot 4$ & $21 \cdot 2$ & $28 \cdot 1$ & $137 \cdot 8$ & $66 \cdot 5$ & $20 \cdot 5$ & $21 \cdot 2$ & 123.9 \\
\hline Vienna in Austria & 63.7 & $31 \cdot 7$ & $58 \cdot 2$ & $31 \cdot 0$ & $15 \cdot 1$ & 173.9 & $67 \cdot 2$ & 31.9 & $17 \cdot 6$ & $137 \cdot 3$ \\
\hline Zaragoza in Spain & $62 \cdot 9$ & $19 \cdot 2$ & $62 \cdot 9$ & $22 \cdot 2$ & 24.4 & $149 \cdot 8$ & $62 \cdot 9$ & $16 \cdot 4$ & $34 \cdot 3$ & 93.9 \\
\hline Stockholm in Sweden & $58 \cdot 7$ & $23 \cdot 1$ & 52.4 & $20 \cdot 1$ & $21 \cdot 2$ & 131.9 & $64 \cdot 6$ & $24 \cdot 3$ & $12 \cdot 1$ & $140 \cdot 0$ \\
\hline Pecs in Hungary & $57 \cdot 8$ & $20 \cdot 0$ & $60 \cdot 9$ & $22 \cdot 6$ & $24 \cdot 2$ & 138.0 & $55 \cdot 6$ & $17 \cdot 8$ & $25 \cdot 5$ & 119.8 \\
\hline Lille in France & 54.9 & 24.5 & $60 \cdot 2$ & $27 \cdot 1$ & $12 \cdot 4$ & 139.6 & $51 \cdot 1$ & 21.9 & 11.4 & $90 \cdot 2$ \\
\hline Gent in Belgium & $52 \cdot 3$ & $22 \cdot 8$ & 49.9 & $22 \cdot 6$ & $12 \cdot 2$ & $103 \cdot 2$ & $54 \cdot 7$ & $22 \cdot 9$ & $15 \cdot 2$ & $105 \cdot 9$ \\
\hline Heraklion in Crete & $51 \cdot 3$ & 13.4 & 51.9 & $12 \cdot 4$ & $25 \cdot 1$ & 88.4 & $50 \cdot 7$ & 14.4 & 14.4 & 84.3 \\
\hline Dortmund in Germany & $49 \cdot 3$ & $21 \cdot 8$ & $48 \cdot 1$ & $17 \cdot 7$ & $21 \cdot 6$ & $98 \cdot 1$ & $51 \cdot 0$ & $27 \cdot 1$ & $13 \cdot 2$ & $160 \cdot 7$ \\
\hline
\end{tabular}

observed in the centile curves in Fig. 2, as Tanner stages differ and girls are on average 2 years in advance within the maturation process. In the US study by Yetley ${ }^{(45)}$ deficiency percentage also increased with increasing age (1\% for infants and children aged $<11$ years, 5\% for adolescents aged 12-19 years and $6 \%$ for adults aged $<20$ years).

Several reports have observed a relationship between BMI and vitamin D concentrations ${ }^{(52)}$. An inverse, but not significant, relationship between $25(\mathrm{OH}) \mathrm{D}$ and BMI was found in the HELENA sample (Table 3). In the literature there are discrepancies regarding this issue. While several studies reported a significant and inverse relationship ${ }^{(46,53,54)}$, others did not find any associations of BMI and/or fat mass with 25(OH)D levels in the paediatric population ${ }^{(55,56)}$. This may be attributed, in part, to BMI-based categorisation of obesity and the variations associated with growth and development. There are also studies reporting that obesity is associated with decreased bioavailability of dietary and cutaneously synthesised vitamin D. This may be secondary to the sequestration of vitamin D into a larger pool of adipose tissue $\mathrm{S}^{(57)}$

As we have reviewed recently ${ }^{(19)}$, both geographical and seasonal differences can be appreciated throughout Europe when analysing independent studies. Owing to the complex methodology and the multiple objectives of the HELENA study, no specific calendar for vitamin D sampling could be established, which would have contributed to getting a more in-depth appreciation of these aspects. Although not assessed in the study, dietary vitamin D intake and personal UV exposure habits may partly explain geographical differences in vitamin D status. Nevertheless, our study data are similar to those published by others ${ }^{(20,24,27,28,43,44)}$, as the highest concentrations were observed in Rome, Athens and Zaragoza, and the lowest concentrations in Dortmund, Gent and Lille. The low mean concentrations observed in Heraklion could be due to seasonal influences. Because of local logistics, blood sampling in Heraklion was performed only in February and March, two winter months, while in the other centres, with the exception of Athens, blood sampling was distributed throughout the school year (see Annex). The low concentrations obtained in Heraklion could indicate a risk during the winter months even in the Mediterranean countries.
This is in accordance with some researchers who have already emphasised the need to supplement vitamin $\mathrm{D}$ due to low $25(\mathrm{OH}) \mathrm{D}$ concentrations ${ }^{(58,59)}$, especially during winter months. The high mean concentrations observed in Vienna need further analysis, which is out of the scope of this article. All in all, the detected geographical differences make it difficult to give common recommendations to improve vitamin D status in adolescents at the European level.

Increasing mean 25(OH)D blood levels up to $40 \mathrm{ng} / \mathrm{ml}$ would have a positive impact on reducing the direct and indirect economic burden of disease ${ }^{(60)}$.

Apart from the aforementioned limitation, the HELENA study has several strengths. The sampling procedure and the strict standardisation of the fieldwork among the countries involved in the study avoided to a great extent the kind of confounding bias due to inconsistent protocols and different laboratory methods, which makes comparing results from isolated studies difficult. The main contribution of the present data is, for the first time, to give a global overview of adolescent vitamin D status in Europe. In the absence of reference values and specific cut-off points for this age group, percentile distribution as presented can be used in clinics and further research. It is important to remember that current blood concentrations of vitamins in the adolescent population do not necessary mean that these concentrations are the most adequate ones from the biological point of view. For a future study, serum parathyroid hormone concentrations should be included as in children and adolescents, the relationship between serum 25(OH)D and parathyroid hormone is less clear $^{(61)}$. Owing to the complex and enormous amount of variables analysed in the HELENA project, parathyroid hormone could not be assessed. Considering the cut-offs used, deficiencies have been observed. Apart from an insufficiency, this could indicate that vitamin D concentrations in adolescents may be different from those of adults, making it necessary to establish general cut-offs for this micronutrient concentration in blood for the adolescence period.

In conclusion, our data give descriptive information about vitamin D status in European adolescents. Age, sex and weight status seem to have an influence on blood concentrations and should be taken into account. Our study results, 
with the limitations described earlier, indicate that vitamin D deficiency is a highly prevalent condition in European adolescents and needs to be addressed by public health authorities.

\section{Disclosure}

The content of this paper reflects only the authors' view and the rest of HELENA study members are not responsible for it. The writing group takes sole responsibility for the content of this article.

\section{Acknowledgements}

The HELENA study has taken place with the financial support of the European Community Sixth RTD Framework Programme (contract FOOD-CT-2005-007034). The content of this article reflects only the authors' views and the European Community is not liable for any use that may be made of the information contained therein. Additional support was received from the Spanish Ministry of Education (AGL200729784-E/ALI; AP-2005-3827) and Universidad Politécnica de Madrid (CH/018/2008). Many thanks to Adelheid Schuch for her contribution to laboratory work, to Laura Barrios for statistical assistance and to Diane Schofield for final English review of the manuscript. None of the authors had any conflict of interests. Contributions of each author: M. G.-G., L. A. M., M. K., S. D. H., F. G., A. K., Y. M., M. F. and P. S. designed the HELENA study and conducted research (recruitment of adolescents, collection of data, and blood sampling; J. V., C. B., E. A. conducted research and performed blood analysis; M. G.-G. and J. V. performed statistical analysis; M. G.-G., J. V., C. B., L. A. M., M. K. and P. S. wrote the paper. M. G.-G. and P. S. had primary responsibility for final content. All authors read and approved the final manuscript.

\section{Helena Study Group}

\section{Co-ordinator: Luis A. Moreno.}

Core Group members: Luis A. Moreno, Fréderic Gottrand, Stefaan De Henauw, Marcela González-Gross, Chantal Gilbert. Steering Committee: Anthony Kafatos (President), Luis A. Moreno, Christian Libersa, Stefaan De Henauw, Jackie Sáchez, Fréderic Gottrand, Mathilde Kesting, Michael Sjostrom, Dénes Molnár, Marcela González-Gross, Jean Dallongeville, Chantal Gilbert, Gunnar Hall, Lea Maes, Luca Scalfi.

Project Manager: Pilar Meléndez.

1. Universidad de Zaragoza (Spain): Luis A. Moreno, Jesús Fleta, José A. Casajús, Gerardo Rodríguez, Concepción Tomás, María I. Mesana, Germán Vicente-Rodríguez, Adoración Villarroya, Carlos M. Gil, Ignacio Ara, Juan Revenga, Carmen Lachen, Juan Fernández Alvira, Gloria Bueno, Aurora Lázaro, Olga Bueno, Juan F. León, Jesús Ma a Garagorri, Manuel Bueno, Juan Pablo Rey López, Iris Iglesia, Paula Velasco, Silvia Bel.

2. Consejo Superior de Investigaciones Científicas (Spain): Ascensión Marcos, Julia Wärnberg, Esther Nova, Sonia
Gómez, Esperanza Ligia Díaz, Javier Romeo, Ana Veses, Mari Angeles Puertollano, Belén Zapatera, Tamara Pozo.

3. Université de Lille 2 (France): Laurent Beghin, Christian Libersa, Frédéric Gottrand, Catalina Iliescu, Juliana Von Berlepsch.

4. Research Institute of Child Nutrition Dortmund, Rheinische Friedrich-Wilhelms-Universität Bonn (Germany): Mathilde Kersting, Wolfgang Sichert-Hellert, Ellen Koeppen.

5. Pécsi Tudományegyetem (University of Pécs) (Hungary): Dénes Molnar, Eva Erhardt, Katalin Csernus, Katalin Török, Szilvia Bokor, Mrs. Angster, Enikö Nagy, Orsolya Kovács, Judit Repásy.

6. University of Crete School of Medicine (Greece): Anthony Kafatos, Caroline Codrington, María Plada, Angeliki Papadaki, Katerina Sarri, Anna Viskadourou, Christos Hatzis, Michael Kiriakakis, George Tsibinos, Constantine Vardavas Manolis Sbokos, Eva Protoyeraki, Maria Fasoulaki.

7. Institut für Ernährungs- und Lebensmittelwissenschaften -Ernäbrungphysiologie. Rheinische Friedrich Wilhelms Universität (Germany): Peter Stehle, Klaus Pietrzik, Marcela González-Gross, Christina Breidenassel, Andre Spinneker, Jasmin Al-Tahan, Miriam Segoviano, Anke Berchtold, Christine Bierschbach, Erika Blatzheim, Adelheid Schuch, Petra Pickert.

8. University of Granada (Spain): Manuel J. Castillo, Ángel Gutiérrez, Francisco B. Ortega, Jonatan R Ruiz, Enrique G. Artero, Vanesa España-Romero, David Jiménez-Pavón, Palma Chillón.

9. Istituto Nazionale di Ricerca per gli Alimenti e la Nutrizione (Italy): Davide Arcella, Elena Azzini, Emma Barrison, Noemi Bevilacqua, Pasquale Buonocore, Giovina Catasta, Laura Censi, Donatella Ciarapica, Paola D'Acapito, Marika Ferrari, Myriam Galfo, Cinzia Le Donne, Catherine Leclercq, Giuseppe Maiani, Beatrice Mauro, Lorenza Mistura, Antonella Pasquali, Raffaela Piccinelli, Angela Polito, Raffaella Spada, Stefania Sette, Maria Zaccaria.

10. University of Napoli "Federico II" Dept of Food Science (Italy): Luca Scalfi, Paola Vitaglione, Concetta Montagnese.

11. Ghent University (Belgium): Ilse De Bourdeaudhuij, Stefaan De Henauw, Inge Huybrechts, Tineke De Vriendt, Lea Maes, Christophe Matthys, Carine Vereecken, Mieke de Maeyer, Charlene Ottevaere.

12. Medical University of Vienna (Austria): Kurt Widhalm, Katharina Phillipp, Sabine Dietrich, Birgit Kubelka Marion Boriss-Riedl.

13. Harokopio University (Greece): Yannis Manios, Eva Grammatikaki, Zoi Bouloubasi, Tina Louisa Cook, Sofia Eleutheriou, Orsalia Consta, George Moschonis, Ioanna Katsaroli, George Kraniou, Stalo Papoutsou, Despoina Keke, Ioanna Petraki, Elena Bellou, Sofia Tanagra, Kostalenia Kallianoti, Dionysia Argyropoulou, Katerina Kondaki, Stamatoula Tsikrika, Christos Karaiskos.

14. Institut Pasteur de Lille (France): Jean Dallongeville, Aline Meirhaeghe.

15. Karolinska Institutet (Sweden): Michael Sjöstrom, Patrick Bergman, María Hagströmer, Lena Hallström, Mårten Hallberg, Eric Poortvliet, Julia Wärnberg, Nico Rizzo, Linda Beckman, Anita Hurtig Wennlöf, Emma Patterson, Lydia Kwak, Lars Cernerud, Per Tillgren, Stefaan Sörensen. 
16. Asociación de Investigación de la Industria Agroalimentaria (Spain): Jackie Sánchez-Molero, Elena Picó, Maite Navarro, Blanca Viadel, José Enrique Carreres, Gema Merino, Rosa Sanjuán, María Lorente, María José Sánchez, Sara Castelló.

17. Campden \& Chorleywood Food Research Association (United Kingdom): Chantal Gilbert, Sarah Thomas, Elaine Allchurch, Peter Burguess.

18. SIK - Institutet foer Livsmedel och Bioteknik (Sweden): Gunnar Hall, Annika Astrom, Anna Sverkén, Agneta Broberg.

19. Meurice Recherche \& Development asbl (Belgium): Annick Masson, Claire Lehoux, Pascal Brabant, Philippe Pate, Laurence Fontaine.

20. Campden \& Chorleywood Food Development Institute (Hungary): Andras Sebok, Tunde Kuti, Adrienn Hegyi.

21. Productos Aditivos SA (Spain): Cristina Maldonado, Ana Llorente.

22. Cárnicas Serrano SL (Spain): Emilio García.

23. Cederroth International AB (Sweden): Holger von Fircks, Marianne Lilja Hallberg, Maria Messerer.

24. Lantmännen Food RED (Sweden): Mats Larsson, Helena

Fredriksson, Viola Adamsson, Ingmar Börjesson.

25. European Food Information Council (Belgium): Laura Fernández, Laura Smillie, Josephine Wills.

26. Universidad Politécnica de Madrid (Spain): Marcela González-Gross, Jara Valtueña, David Jiménez-Pavón, Ulrike Albers, Raquel Pedrero, Agustín Meléndez, Pedro J. Benito, Juan José Gómez Lorente, David Cañada, Alejandro Urzanqui, Juan Carlos Ortiz, Francisco Fuentes, Rosa María Torres, Paloma Navarro.

\section{References}

1. Ovesen L, Andersen R \& Jakobsen (2003) Geographical differences in vitamin D status, with particular reference to European countries. J Proc Nutr Soc 62, 813-821.

2. Prentice A, Branca F, Decsi T, et al. (2004) Energy and nutrient dietary reference values for children in Europe: methodological approaches and current nutritional recommendations. Br J Nutr 92, Suppl. 2, S83-S146.

3. Moreno LA (2008) Adolescence. In Pediatric Nutrition in Practice, pp. 114-117 [B Koletzko, editor]. Basel: Karger.

4. Bischoff-Ferrari H (2010) Health effects of vitamin D. Dermatol Ther 23, 23-30.

5. Bischoff-Ferrari HA, Dietrich T, Orav EJ, et al. (2004) Positive association between 25-hydroxy vitamin D levels and bone mineral density: a population-based study of younger and older adults. Am J Med 116, 634-639.

6. Scharla SH, Scheidt-Nave C, Leidig G, et al. (1996) Lower serum 25-hydroxyvitamin $\mathrm{D}$ is associated with increased bone resorption markers and lower bone density at the proximal femur in normal females: a population-based study. Exp Clin Endocrinol Diabetes 104, 289-292.

7. Annweiler C, Allali G, Allain P, et al. (2009) Vitamin D and cognitive performance in adults: a systematic review. Eur J Neurol 16, 1083-1089.

8. Elmadfa I, Godina-Zarfl B, Dichtl M, et al. (1994) The Austrian study on nutritional status of 6- to 18-year-old pupils. Bibl Nutr Dieta 51, 62-67.

9. Summerbell CD, Waters E, Edmunds LD, et al. (2005) Interventions for preventing obesity in children. The Cochrane Database of Systematic Reviews issue 3, CD001871.
10. Stoffman N \& Gordon CM (2009) Vitamin D and adolescents: what do we know? Curr Opin Pediatr 21, 465-471.

11. Rolland-Cachera MF, Bellisle F \& Deheeger M (2000) Nutritional status and food intake in adolescents living in Western Europe. Eur J Clin Nutr 54, Suppl. 1, S41-S46.

12. Rizzoli R, Bianchi ML, Garabédian M, et al. (2009) Maximizing bone mineral mass gain during growth for the prevention of fractures in the adolescents and the elderly. Bone 46, 294-305.

13. Lamberg-Allardt C \& Viljakainen H (2008) 25-Hydroxyvitamin $\mathrm{D}$ and functional outcomes in adolescents. $\mathrm{Am} \mathrm{J}$ Clin Nutr 88, Suppl., 534S-536S.

14. Cranney A, Weiler HA, O'Donnell S, et al. (2008) Summary of evidence-based review on vitamin D efficacy and safety in relation to bone health. Am J Clin Nutr 88, 513S-519S.

15. Scharla SH (1998) Prevalence of subclinical vitamin D deficiency in different European countries. Osteoporos Int 8, Suppl. 2, S7-S12.

16. Zerwekh JE (2008) Blood biomarkers of vitamin D status. Am J Clin Nutr 87, Suppl., 1087S-1091S.

17. Millen AE \& Bodnar LM (2008) Vitamin D assessment in population-based studies: a review of the issues. Am J Clin Nutr 87, Suppl., 1102S-1105S.

18. Institute of Medicine (2011) Dietary Reference Intakes for Calcium, Phosphorus, Magnesium, Vitamin D and Fluoride. Standing Committee on the Scientific Evaluation of Dietary Reference Intakes, Food and Nutrition Board, Institute of Medicine. Washington, DC: National Academy Press.

19. Valtueña J, Breidenassel C, Folle J, et al. (2011) Retinol, $\beta$-carotene, $\alpha$-tocopherol and vitamin D status in European adolescents. Regional differences and variability: a review. Nutr Hosp 26, 278-286.

20. Guillemant J, Le HT, Maria A, et al. (2001) Wintertime vitamin D deficiency in male adolescents: effect on parathyroid function and response to vitamin $\mathrm{D}_{3}$ supplements. Osteoporos Int 12, 875-879.

21. Andersen R, Molgaard C, Skovgaard LT, et al. (2005) Teenage girls and elderly women living in northern Europe have low winter vitamin D status. Eur J Clin Nutr 59, 533-541.

22. Gregory JR, Lowe S, Bates CJ, et al. (2000) National Diet and Nutrition Survey: Young People Aged 4 to 18 years. Report of the Diet and Nutrition Survey. London: HMSO.

23. Ross AC, Manson JE, Abrams SA, et al. (2011) The 2011 report on dietary reference intakes for calcium and vitamin $\mathrm{D}$ from the Institute of Medicine: what clinicians need to know. J Clin Endocrinol Metab 96, 53-58.

24. Moreno L, de Henauw S, Gonzalez-Gross M, et al. (2008) Design and implementation of the Healthy Lifestyle in Europe by Nutrition in Adolescence Cross-Sectional Study. Int J Obes 32, Suppl. 5, S4-S11.

25. Bonofiglio D, Maggiolini M, Marsico S, et al. (1999) Critical years and stages of puberty for radial bone mass apposition during adolescence. Horm Metab Res 31, 478-482.

26. Lambert J, Agostoni C, Elmadfa I, et al. (2004) Dietary intake and nutritional status of children and adolescents in Europe. Br J Nutr 92, Suppl. 2, S147-S211.

27. De Henauw S, Gottrand F, De Bourdeaudhuij IM, et al. (2007) Nutritional status and lifestyles of adolescents from a public health perspective. The HELENA project - healthy lifestyle in Europe by nutrition in adolescence. J Public Health $\mathbf{1 5}$, 187-197.

28. Beghin L, Castera M, Manios Y, et al. (2008) Quality assurance of ethical issues and regulatory aspects relating to good clinical practices in the HELENA cross sectional study. Int J Obes (Lond) 32, Suppl. 5, S4-S11.

29. González-Gross M, Breidenassel C, Gómez S, et al. (2008) Use of fresh blood samples to analyse multiple nutritional 
biomarkers in a European nutritional study. Experience from the HELENA cross sectional pilot study. Int J Obes (Lond) 32 , Suppl. 5, S4-S11.

30. Markou KB, Mylonas P, Theodoropoulou A, et al. (2004) The influence of intensive physical exercise on bone acquisition in adolescent elite female and male artistic gymnasts. J Clin Endocrinol Metab 89, 4383-4387.

31. Misra M, Aggarwal A, Miller KK, et al. (2004) Effects of anorexia nervosa on clinical, hematologic, biochemical, and bone density parameters in community-dwelling adolescent girls. Pediatrics 114, 1574-1583.

32. Nagy E, Vicente-Rodriguez G, Manios Y, et al. (2008) Harmonization process and reliability assessment of anthropometric measurements in a multicenter epidemiologic study in adolescents. Int J Obes (Lond) 32, S58-S65.

33. Tanner JM \& Whitehouse RH (1976) Clinical longitudinal standards for height, weight, height velocity, weight velocity, and stages of puberty. Arch Dis Child 51, 170-179.

34. Malabanan A, Veronikis IE, Holick MF, et al. (1998) Redefining vitamin D insufficiency. Lancet 351, 805-806.

35. Bischoff-Ferrari HA, Giovannucci E, Willett WC, et al. (2006) Estimation of optimal serum concentrations of 25-hydroxyvitamin D for multiple health outcomes. Am J Clin Nutr 84, 18-28.

36. Cole TJ \& Green PJ (1992) Smoothing reference centile curves: the LMS method and penalized likelihood. Stat Med 11, 1305-1319.

37. Cole TJ, Freeman JV \& Preece MA (1998) British 1990 growth reference centiles for weight, height, body mass index and head circumference fitted by maximum penalized likelihood. Stat Med 17, 407-429.

38. Van der Wielen PJ, de Groot LCPG, van Staveren WA, et al. (1995) Serum vitamin D concentrations among elderly people in Europe. Lancet 346, 207-210.

39. Carter GD, Carter CR, Gunter E, et al. (2004) Measurement of vitamin D metabolites: an international perspective on methodology and clinical interpretation. J Steroid Biochem Mol Biol 89-90, 467-471.

40. Binkley N, Krueger D, Cowgill CS, et al. (2004) Assay variation confounds the diagnosis of hypovitaminosis D: a call for standardization. J Clin Endocrinol Metab 89, 3152-3157.

41. Lips P, Chapuy MC, Dawson-Hughes B, et al. (1999) An international comparison of serum 25-hydroxyvitamin D measurements. Osteoporos Int 9, 394-397.

42. Carter GD, Carter R, Jones J, et al. (2004) How accurate are assays for 25-hydroxyvitamin D? Data from the international vitamin D external quality assessment scheme. Clin Chem 50, 2195-2197.

43. Lehtonen-Veromaa M, Möttönen T, Irjala K, et al. (1999) Vitamin D intake is low and hypovitaminosis D common in healthy 9- to 15-year-old Finnish girls. Eur J Clin Nutr 53, 746-751.

44. Hill TR, Cotter AA, Mitchell S, et al. (2008) Vitamin D status and its determinants in adolescents from the Northern Ireland Young Hearts 2000 cohort. Br J Nutr 99, 1061-1067.

45. Yetley EA (2008) Assessing the vitamin D status of the US population. Am J Clin Nutr 88, Suppl., 558S-564S.
46. Kaur H, Hyder ML \& Poston WS (2003) Childhood overweight: an expanding problem. Treat Endocrinol 2, 375-388.

47. Dong Y, Pollock N, Stallmann-Jorgensen IS, et al. (2010) Low 25-hydroxyvitamin D levels in adolescents: race, season, adiposity, physical activity, and fitness. Pediatrics $\mathbf{1 2 5}$, $1104-1111$.

48. Rovner AJ \& O'Brien KO (2008) Hypovitaminosis D among healthy children in the United States: a review of the current evidence. Arch Pediatr Adolesc Med 162, 513-519.

49. Langlois K, Greene-Finestone L, Little J, et al. (2010) Vitamin D status of Canadians as measured in the 2007 to 2009 Canadian Health Measures Survey. Health Rep 21, $47-55$.

50. Lanham-New SA, Buttriss JL, Miles LM, et al. (2011) Proceedings of the Rank Forum on vitamin D. Br J Nutr 105, $144-156$.

51. Koenig J \& Elmadfa I (2000) Status of calcium and vitamin D of different population groups in Austria. Int J Vitam Nutr Res 70, 214-220.

52. Souberbielle JC, Friedlander G, Kahan A, et al. (2006) Evaluating vitamin D status. Implications for preventing and managing osteoporosis and other chronic diseases. Joint Bone Spine 73, 249-253.

53. Smotkin-Tangorra $\mathrm{M}$, Purushothaman $\mathrm{R}$, Gupta $\mathrm{A}$, et al. (2007) Prevalence of vitamin D insufficiency in obese children and adolescents. J Pediatr Endocrinol Metab 20 $817-823$.

54. Lenders CM, Feldman HA, Von Scheven E, et al. (2009) Relation of body fat indexes to vitamin D status and deficiency among obese adolescents. Am J Clin Nutr 90, 459-467.

55. Jago R, Harrell JS, McMurray RG, et al. (2006) Prevalence of abnormal lipid and blood pressure values among an ethnically diverse population of eighth-grade adolescents and screening implications. Pediatrics 117, 2065-2073.

56. Weng FL, Shults J, Leonard MB, et al. (2007) Risk factors for low serum 25-hydroxyvitamin D concentrations in otherwise healthy children and adolescents. Am J Clin Nutr 86, 150-158.

57. Holick MF (2007) Vitamin D deficiency. N Engl J Med 357, 266-281.

58. Serra-Majem L (2001) Vitamin and mineral intakes in European children. Is food fortification needed? Public Health Nutr 4, 101-107.

59. Pilz S, Tomaschitz A, Drechsler C, et al. (2011) Vitamin D supplementation: a promising approach for the prevention and treatment of strokes. Curr Drug Targets 12, 88-96.

60. Grant WB, Cross HS, Garland CF, et al. (2009) Estimated benefit of increased vitamin $D$ status in reducing the economic burden of disease in western Europe. Prog Biophys Mol Biol 99, 104-113.

61. Hill KM, McCabe GP, McCabe LD, et al. (2010) An inflection point of serum 25-hydroxyvitamin D for maximal suppression of parathyroid hormone is not evident from multi-site pooled data in children and adolescents. J Nutr 140 , 1983-1988. 


\section{NS British Journal of Nutrition}

Annex. Blood sampling calendar: number of subjects (age range) per city, during the sampling period

\begin{tabular}{|c|c|c|c|c|c|c|c|c|c|c|}
\hline \multirow[b]{2}{*}{ City } & \multicolumn{10}{|c|}{ Month } \\
\hline & $\begin{array}{l}\text { October } \\
2006\end{array}$ & $\begin{array}{l}\text { November } \\
2006\end{array}$ & $\begin{array}{l}\text { December } \\
2006\end{array}$ & $\begin{array}{l}\text { January } \\
2007\end{array}$ & $\begin{array}{l}\text { February } \\
2007\end{array}$ & $\begin{array}{l}\text { March } \\
2007\end{array}$ & $\begin{array}{l}\text { April } \\
2007\end{array}$ & $\begin{array}{l}\text { May } \\
2007\end{array}$ & $\begin{array}{l}\text { June } \\
2007\end{array}$ & $\begin{array}{l}\text { October } \\
2007\end{array}$ \\
\hline Athens & & $\begin{array}{c}88 \\
\text { (12.6-16.9 years) }\end{array}$ & $\begin{array}{c}37 \\
\text { (13.1-15.4 years) }\end{array}$ & & & & & & & \\
\hline Crete & & & & & $\begin{array}{c}23 \\
\text { (13.1-14.5 years) }\end{array}$ & $\begin{array}{c}69 \\
\text { (12.6-15.9 years) }\end{array}$ & & & & \\
\hline Dortmund & & & & $\begin{array}{c}57 \\
\text { (12.5-17.3 years) }\end{array}$ & & & $\begin{array}{c}30 \\
\text { (12.8-16.8 years) }\end{array}$ & & $\begin{array}{c}32 \\
\text { (14.2-16.7 years) }\end{array}$ & \\
\hline Gent & $\begin{array}{c}29 \\
\text { (14.8-16.1 years) }\end{array}$ & $\begin{array}{c}16 \\
\text { (13.9-14.9 years) }\end{array}$ & & & $\begin{array}{c}20 \\
\text { (13.3-15.9 years) }\end{array}$ & $\begin{array}{c}13 \\
\text { (16.4-17.4 years) }\end{array}$ & $\begin{array}{c}15 \\
\text { (15.3-16.2 years) }\end{array}$ & $\begin{array}{c}22 \\
\text { (14.4-16.5 years) }\end{array}$ & & \\
\hline Lille & & & $\begin{array}{c}25 \\
\text { (12.5-13.4 years) }\end{array}$ & & & $\begin{array}{c}19 \\
\text { (13.2-14.6 years) }\end{array}$ & & $\begin{array}{c}15 \\
\text { (14.3-15.1 years) }\end{array}$ & $\begin{array}{c}35 \\
\text { (12.9-15.9 years) }\end{array}$ & \\
\hline Pecs & & $\begin{array}{c}3 \\
\text { (14.8-16.8 years) }\end{array}$ & & & & $\begin{array}{c}56 \\
\text { (12.6-17.3 years) }\end{array}$ & & & & \\
\hline Rome & & & $\begin{array}{c}17 \\
\text { (12.6-16.6 years) }\end{array}$ & & & $\begin{array}{c}14 \\
\text { (16. } 1-17.3 \text { years) }\end{array}$ & & $\begin{array}{c}45 \\
\text { (14.3-17.1 years) }\end{array}$ & $\begin{array}{c}9 \\
\text { (14.3-17.4 years) }\end{array}$ & $\begin{array}{c}19 \\
\text { (13.7-17.1 years) }\end{array}$ \\
\hline Stockholm & & & $\begin{array}{c}18 \\
(16.4-16.9 \text { years })\end{array}$ & $\begin{array}{c}40 \\
\text { (14.0-16.7 years) }\end{array}$ & & & $\begin{array}{c}38 \\
\text { (13.2-14.1 vears) }\end{array}$ & $\begin{array}{c}33 \\
\text { (12.6- } 13.3 \text { vears) }\end{array}$ & & \\
\hline Vienna & & $\begin{array}{c}41 \\
\text { (13.7-17.3 years) }\end{array}$ & & & $\begin{array}{c}20 \\
\text { (14.2-16.9 years) }\end{array}$ & $\begin{array}{c}16 \\
\text { (15.8-17.0 years) }\end{array}$ & & $\begin{array}{c}43 \\
\text { (14.7-17.0 years) }\end{array}$ & & \\
\hline Zaragoza & & & $\begin{array}{c}19 \\
\text { (12.5-14.6 years) }\end{array}$ & & $\begin{array}{c}15 \\
\text { (14.9-17.1 years) }\end{array}$ & $\begin{array}{c}38 \\
\text { (13.9- } 15.8 \text { years) }\end{array}$ & & $\begin{array}{c}37 \\
\text { (13.4-15.2 years) }\end{array}$ & $\begin{array}{c}15 \\
(12 \cdot 6-16 \cdot 4 \text { years })\end{array}$ & \\
\hline
\end{tabular}

